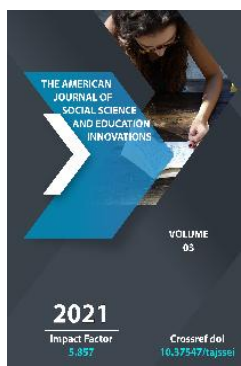

\title{
Modern Interpretations Of The Creative Style Of Kamoliddin Behzod In The Works Of Artists Of Uzbekistan
}

\author{
Tolkun Akhmedov \\ Senior Lecturer, National Institute Of Art And Design Named After K. Behzod Department Of \\ "History And Theory Of Art", Uzbekistan
}

Journal Website:

http://theamericanjour

nals.com/index.php/taj

ssei

Copyright: Original content from this work may be used under the terms of the creative commons attributes 4.0 licence.

\section{ABSTRACT}

The article discusses about the artists who in their works used the tavorik style of the artist's miniature K. Behzod and used them and used the things created in their works in modern solutions. They solve the compositional structure and artistic solution of their works in an unexpected way. They also manage to express free creative space and time directly in these works.

\section{KEYWORDS}

Miniature, style, composition, decorativeness, modern, conditional, flowers, middle ages, Islamic art, linear images.

\section{INTRODUCTION}

Miniature artists Bakhodir Khodjimetov and their son Behzod Khodjimetov pay great attention to the image of K. Behzod and create new works in their own way, creatively and critically using the traditions of miniature art. They do not use miniature lines directly in 
their paintings, but use modern paints using modern paints that resemble the watercolor style of painting. They solve the compositional structure and artistic solution of their works in an unexpected way. They also manage to express free creative space and time directly in these works. Some of his works are also experimented with to give a modern spirit and tone.

By the decision of the Cabinet of Ministers of the Republic of Uzbekistan dated December 27, 1997 and UNESCO in 2000, the celebration of the 545th anniversary of the master of oriental miniature of the XV century Kamoliddin Behzod was announced in our country, which was widely celebrated. on the international level. Now, 20 years later, by the decision of the President of the Government of Uzbekistan, in October 2020, it was announced that the 565th anniversary of the famous Oriental artist Kamoliddin Behzod will be celebrated in an expanded manner.

\section{THE MAIN FINDINGS AND RESULTS}

Previously, the Academy of Arts of Uzbekistan was responsible for the anniversary events. An album has been prepared by the Academy of Arts of Uzbekistan, the Art Research Institute, the Directorate of Art Exhibitions and UNESCO in connection with this conference and the anniversary. Art critics, E.Ismailova and Z.Rahimova, who compiled and prepared the album for publication [11] managed to gather huge amounts of valuable data. According to him, the authors included copies of the works of K. Behzod in Cairo, London, Britain, Boston, Oxford, Bodleian libraries, museums in St. Petersburg, which allowed to regularly display the unique works of the great artist in Uzbekistan. Well-known artist S.Rakhmetov, well-known art critic O.lbragimov, well-known writer, art critic N.Normatov were responsible for preparing this album for publication.

In addition, the book "K. Behzod" was published by orientalists and art historians O.Usmanov and A.Madrahimov, dedicated to the 545th anniversary of the great Uzbek artist [12]. This book tells about the life and work of Behzod, a student of Alisher Navoi, one of the representatives of the XV century Renaissance in Movarounnakhr and Khorasan, "Sharq Rafaeli", the great artist and scholar Behzod, his creative relationship with Alisher Navoi, his works are covered.

K. Behzod's work is being studied with great interest by art lovers around the world. Thus, there is reason to believe that the influence of the works of the great Uzbek artist K. Behzod is gaining ground in the modern artistic process.

Opening of the educational program "Calligraphy and Miniature" at the National Institute of Art and Design. Kamoliddin Behzod in 1999 was the first important step in the formation of a new generation of miniature masters. B.Khojimetov, who studied at this university and successfully completed his bachelor's and master's degrees and is currently training a number of students, is one of the artists who is determined to continue the traditions of a teacher. His first teacher was his father, the miniature artist Bahodir Khojimetov, who from a young age studied the secrets of fine arts in the workshop founded by his father and fell in love with him.

Behzod was first led by Vahob Ziyoev in a school-age circle. Then he studied under 
Abdusamat Saidberdiev in the "Painting" department of the Republican Art School named after P.P. Benkov. After graduating from the National Institute of Art and Design named after K. Behzod in the direction of "Calligraphy and Miniature" under the leadership of Niyazali Kholmatov, Alisher Mirzaev, Mirkhamid Sobirov and Sodiq Rakhmonov, he mastered the secrets of Oriental miniature. Today, in the works created by Behzod Khojimetov, you can see the knowledge he received from his teachers and the product of his tireless research.

At the next exhibition "Oriental Fine Arts in the Eyes of Youth-III" organized at the Museum of Oriental Miniature Art named after Kamoliddin Behzod, the works of Behzod Khojimetov and his students in the way of miniatures were traditionally presented for the third time.

The achievements of Behzod Khojimetov over more than 10 years of pedagogical activity are a vivid example of the continuity of teacherstudent traditions. The artist is faithful to the tradition and pays tribute to the master artist Kamoliddin Behzod, his work. For this reason, he often appeals to the creation of an artistic image of a great artist. As a master of the brush, creatively and critically using the traditions of miniature art associated with bench painting, he places great emphasis on creating works in a new visual solution. In some of the works depicted by the artist, he directly uses the tradition typical of the Iranian style of miniature drawings, applying freecolor greases in a watercolor style in the direction of bench painting. Decides on the compositional structure and artistic solution of the work in the appearance of unexpected plots. In this way, they are able to directly express the free creative space and time. Some of the works of the artist are approached as a separate experiment to give the spirit and tone of modernity.

In his work "Portrait of Kamoliddin Behzod" by the artist Behzod Khodjimetov, he depicts a close-up, with an enlarged face, the head of the great artist of the East and a mature figure in a compositional solution vertically up to the waist, looking at the next generation. By giving the artist's figure in space the shape of a circular ring that symbolizes the water of the Middle Ages on a blue background, the artist expresses his idea in a visual image rich in philosophical content. In this portrait one can clearly see the emergence of the artist's originality and aspirations.

"Kamoliddin Behzod" was created in 2004 as a result of the use of conventional and old drawing traditions of miniature, using art objects and bench tools. The colors used in this trilogy, according to the ideological content of K. Behzod's Alisher Navoi and Hussein Boykaro, emphasize the traditions of teachers and students, which have survived to the present day through the use of multilayered compositional solutions and unique methods of expression. At the same time, the artist B.Khojimetov himself demonstrates that he continues the tradition of teacher-student at the institute, which he currently conducts with students of the miniature department.

The works of the artist B.Khojimetov, in which the rich inter-color relations take the viewer into the ocean of deep thoughts, that is, into the abyss of the abyss, that is, into the art of the Islamic period. The next trilogy of the creator "Ushshak" also tells the story of Islam, fantasy, oriental love. The skillful application 
of the unique ancient methods and techniques of miniature art, at the same time, is guided by the principle of depiction of this work on the basis of a compositional solution in the modern spirit. In this work, the artist was able to find a way to combine shapes and colors on a scientific basis and brought to it a kind of musical, oriental, lyrical tone. The two left and right sides of the trio are represented by two young figures who are flying in an ocean of sweet dreams, having long waited to reach each other's visions. At the center of the composition, he was able to write through the application of a perfect, artistic solution that the moment of reaching visal for them had come, the moment of holding an Islamic wedding, an intermarriage with each other on the basis of oriental traditions, Muslim traditions.

In the center of another colorful composition by the artist Behzod Khodjimetov, "Mother's Love", he shook the cradle to put his child in the cradle, and, finally, under the influence of the goddess, he described the irreplaceable moments of the mother and child in this delicate moment in a delicate, sweet, and pleasurable sleep, while the young mother, who had unknowingly fallen asleep, poured all her love for her child. In the content of the work, the idea of humanism, introduced into the fine arts in the image of Leonardo da Vinci and Raphael Santi madonna in the Italian "Renaissance", found its Uzbek expression in the form of "oriental" Islamic culture. The blue and green tones of the background are positively integrated into the overall ideological content of the work. It feels that the oriental, national life, Islamic culture and traditions have been applied in their place.
B.Khojimetov's work "Sheikh San'on" in the form of a trilogy reflected in a complex compositional solution is noteworthy. At the center of the work is the image of a sheikh who went to the land of non-religions in the work of the queen of another country. Sheikh San'on, a well-known figure in the Islamic world, dreamed of a princess who agreed to do the work of raising a pig to make him his guardian. The idea of the work, which is based on the traditions of this miniature style, is distinguished by the fact that it is written with the help of deep and perfect research, and, of course, with the help of unique modern art paints and unexpected visual solutions.

In the visual arts, there are enough artists and creators who are determined to create a portrait of the teacher $\mathrm{K}$. Behzod, be it color painting, graphics or sculpture, among them is the century created by the famous sculptor Jalollidin Mirtojiev, a talented sculptor. The statue dedicated to K. Behzod, erected by him in the spring of 2010 near the Central Exhibition Hall of the Academy of Arts of Uzbekistan, was unveiled as part of the Festival of Fine and Applied Arts of Uzbekistan, organized this year in sync with the Museum of Oriental Art named after K. Behzod. The opening ceremony was attended by the leadership of the Academy of Arts, foreign guests and festival participants. Today, the statue is located in front of the Museum of Oriental Art named after $\mathrm{K}$. Behzod, set in an elegant look typical of a slender and miniature artist's figure. Around it, a permanent exhibition of K. Behzod's famous miniature works allows visitors to reminisce about the ancient and modern times of our unique national fine arts, to spend their 
time in a unique open-air garden and to enter the medieval world. creates.

Substantiated opinion of the artist Behzod Khodjimetov on the creative and pedagogical activities of art critic Asalkhon Rakhmatullaeva in the article "Sounds of time in miniature", published in the 2nd issue of the magazine "Art" for 2017[13]. This article also reflects the version of the story "Sheikh San'on" written by the artist Behzod Khojimetov, written in 2006, based on miniature colors and lines in a unique compositional solution. However, Behzod Khojimetov was able to portray the image of K. Behzod many times. In 2005, the artist painted a wooden tray $50 \mathrm{~cm}$ in diameter with a composition of tempera paint and then covered with lacquer "Portrait of Kamoliddin Behzod and achieved this using a multi-layered complex composition.

\section{CONCLUSION}

In conclusion, the next miniature miniature work of K. Behzod, described by the artist in 2011, is written in the form of a rectangular vertical composition in the size of $50 \times 30$. This miniature is painted with tempera paint in a modern style. In its center, K. Behzod alone is represented in the form of deep thoughts and fantasies against the background of the landscape of grass, flowering trees and rocks. The dress worn by the artist is depicted in the form of a white-and-white, embroidered coat with white flowers. In this play, as in the previous work, the artist is sitting with a stick in his hand, his foot on a rock. He is depicted with a turban on his head, a belt at his waist, hair and beard, dark eyebrows with thin lines in harmony with brown.
1. Akilova K. The road to perfection.- Art., 2015.№ 2.

2. Ismoilova E, Rahimova Z. 545th anniversary of Kamoliddin Behzod. 2000, edition of the magazine "Art".Tashkent:.

3. Xakimov A. History of art of Uzbekistan.P. 118-128.

4. Ibrohim Rahimovich Abdurahmonov.Concept of mythologi represented in fine arts of Uzbekistan.//Asian Journal of Multidimensional Researsh. Impact Factor: SJif 2020=6.882. Voll 9, Issue 10, October, 2020. P. 143-147.

5. Ibrokhim Rakhimovich Abdurakhmonov. Reflection of Folklore in Appled Art Of Uzbekistan (From The Beginning Of The XX Century To The gos). The Americen Journal Of Social Science and Education Innovations (ISSN-2689-100X). February 27. 2021. P.166-171. https://doi. org/10,37547. Impact Factor 202: 5.857.

6. Ibrokhim Abdurakhmanov, (2019) "Specific peculiarities and value of legendary themes in the practical apply art," Culture and Arts of Central Asia: Vol. 10:No. 1, Article 12. Available at: https://uzjournals.edu.uz/cacenas/vol10/is $\mathrm{s} 1 / 12$.

7. Ibragim Abdurahmonov. Reflection of Written Dastans in Maveraunnahr Miniature (XIV-XVII Centuries)-/l International journal of research With Impact Factor 5.60 December. 2018. P.425-432.

8. Ibrokhim Abdurakhmanov. Evolution of mythological themes in the art of Uzbekistan. Academic research in educational sciences, 2021/3. P.500-508

9. Ibrokhim Rakhimovich Abdurakhmonov. He Interpretation of Images on Dualism, Totemisv, Animism and Fetishism The American Journal of Social Science and 
Education Innovations(ISSN-2689-100X)

P.75-81. Impact Factor 2021.5.857

10. Rahmatullaeva A."Tones of time in miniature" Art. 2017. № 2.

11. Ismoilova E, Rahimova Z. " 545th anniversary of Kamoliddin Behzod. Art magazine. Tashkent:. 2000.

12. Usmonov O., Madrahimov A. "K.Behzod". Publishing House of Sharq Publishing and Printing Concern. Tashkent:.

13. Rahmatullaeva A."Tones of time in miniature". Art. 2017. № 2.

14. Sayfullaev, N. (2021). The Name Of Our Country Will Be Praised By The Followers Of Kamoliddin Bekhzod. The American Journal of Social Science and Education Innovations, 3(04), 402-408.

15. Абдурахмонов, И. (2021). ЎЗБЕКИСТОН САНЪАТИДА МИФОЛОГИК МАВЗУЛАР ЭВолюциясИ. Academic research in educational sciences, 2(3).।

16. Djumaniyazova, D. (2021). Humanity And Divinity Are The Objects Of Sufi Teachings. The American Journal of Social Science and Education Innovations, 3(03), 16-26.

17. Nematov, O. THE PILGRIMAGE OF KHAZRAT ZAYNULOBIDIN. Zbiór artykułów naukowych recenzowanych., 83.

18. Dadamukhamedov, B. (2021). Jewellery Of Uzbekistan: Equipment And Technology. The American Journal of Social Science and Education Innovations, 3(03), 212-217. 